\title{
ДИНАМІКА ПОКАЗНИКІВ АНТИОКСИДАНТНОГО ЗАХИСТУ СЛИЗОВОЇ ОБОЛОНКИ ПАРОДОНТА ЗА УМОВ ЕКСПЕРИМЕНТАЛЬНОГО ПАРОДОНТИТУ ПРИ ЗМІНЕНІЙ РЕАКТИВНОСТІ ОРГАНІЗМУ
}

\begin{abstract}
Досліджено особливості змін активності ферментів антиоксидантного захисту в слизовій оболонці пародонта тварин. Встановлено, що у групі тварин з нормоергічним типом запальної реакції активність супероксиддисмутази змінюється в бік підвищення несуттєво, а каталази - коливається в межах контролю. У тварин з гіпоергічним типом запальної реакції активність ферментів антиоксидантного захисту змінюється тільки на сьому добу експерименту. В групі тварин з гіперергічним типом запалення відбувається активація ферментів антиоксидантного захисту, і їх активність є найвищою з усіх досліджуваних груп.
\end{abstract}

КЛЮЧОВІ СЛОВА: пародонтит, типи запальної реакції, антиоксидантна система.

ВСТУП. Захворювання пародонта є однією з найактуальніших проблем у медицині через значну поширеність, комплексний характер ураження, залучення до патологічного процесу не лише тканини пародонта, але й інших органів і систем [6, 7]. В Україні, за даними численних епідеміологічних досліджень, поширеність захворювань пародонта серед дорослого населення становить від 92 до 98 \%. При цьому дана патологія уражає як доросле населення, так і дітей [7].

Провідна роль у виникненні запального процесу в пародонті належить патогенній мікрофлорі, але на сьогодні відомі й інші етіологічні чинники, зокрема травматичний [1, $9,15,16]$. Будь-який пошкоджувальний чинник викликає в тканинах пародонта комплекс біохімічних, імунологічних і морфофункціональних змін. Вираження цих змін у кожному організмі буде різним, що залежить від особливостей реактивності організму [2-4].

Загальноприйнятою точкою зору є те, що при різних за місцем дії і локалізації травми процесах основним внутрішньоклітинним процесом є порушення структури біомембран і активація пероксидного окиснення ліпідів. На противагу системі пероксидного окиснення ліпідів існує антиоксидантна система (AOC), діяльність якої направлена на утилізацію токсичних продуктів [3, 8, 12].

(๖) І. Я. Цвинтарна, 2015.
Метою даної роботи було дослідити динаміку показників антиоксидантного захисту в пародонті тварин при нормо-, гіпо- та гіперергічному типах запалення.

МЕТОДИ ДОСЛІДЖЕННЯ. Дослідження проведено на 120 білих нелінійних щурахсамцях масою 170-210 г віком 5-6 місяців. Його виконано відповідно до Європейської конвенції про захист хребетних тварин, що використовуються для дослідних та інших наукових цілей [13], Загальних етичних принципів експериментів на тваринах (Київ, 2001). Пародонтит у щурів моделювали за методикою А. І. Воложина і С. І. Виноградової [5]. Тварин виводили з експерименту на 7-му, 10-ту і 14-ту доби після накладання лігатури. Гіпоергічний тип запальної реакції моделювали шляхом внутрішньом'язового введення алкілуючого цитостатика циклофосфану [11], гіперергічний - внутрішньом'язового введення пірогеналу [11], нормоергічний - за допомогою експериментального пародонтиту без введення будь-яких речовин [5].

Для вивчення системи антиоксидантного захисту було використано біохімічні методи визначення супероксиддисмутази (СОД) [14] та каталази (КАТ) [10].

Дослідженню підлягав гомогенат ясен піддослідної тварини. 
Статистичну обробку результатів виконано у відділі системних статистичних досліджень університету в програмному пакеті Statsoft STATISTICA. Для всіх показників розраховували значення середньої арифметичної вибірки (М), ії дисперсії і помилки середньої (m). Достовірність різниці значень між незалежними кількісними величинами визначали за допомогою критерію Манна-Уїні.

РЕЗУЛЬТАТИ Й ОБГОВОРЕННЯ. БіОХімічНЕ дослідження слизової оболонки тканин пародонта дозволило виявити такі особливості змін ферментів АОС.

Як видно з таблиці 1, у досліджуваній групі тварин (з нормоергічним типом запалення) спостерігали підвищення активності СОД. Зокрема, на сьому добу СОД зростала в 1,6 раза, на десяту дещо знижувалася, але залишалася вищою від контролю в 1,4 раза, а на чотирнадцяту практично була вищою від рівня контролю в 1,5 раза.

Активність ферменту КАТ достовірно підвищувалася відносно показників контрольної групи тварин на сьому добу в 1,2 раза, на десяту і чотирнадцяту доби - була приблизно в межах контролю.

Дещо інші закономірності спостерігали у тварин з гіпоергічним типом запалення (табл. 2).
Активність СОД, порівняно з контролем, на сьому добу зросла в 1,3 раза, а на десяту та чотирнадцяту доби достовірно від контролю не відрізнялась.

Активність КАТ була на сьому добу в 1,1 раза вищою від контролю, а на десяту і чотирнадцяту доби достовірно від контролю не відрізнялась, як і СОД.

За умови нормального обміну СОД підтримує концентрацію супероксидних радикалів на певному рівні, тим самим захищаючи клітинні структури від їх шкідливих впливів. Але коли число вільних радикалів зростає, навантаження на даний фермент збільшується і баланс може порушуватися.

У групі тварин з гіперергічним перебігом запального процесу спостерігали такі зміни показників AOC: так, на сьому добу показники активності СОД достовірно збільшились відносно контролю в 1,6 раза, а на десяту i чотирнадцяту доби підвищились у 1,7 раза (табл. 3).

Активність каталази протягом усього експерименту була такою: на сьому добу дослідження активність КАТ підвищилась у 1,3 раза, на десяту добу зросла у 2 рази, а на чотирнадцяту - у 2,5 раза.

Виражене підвищення СОД і КАТ на чотирнадцяту добу експерименту в слизовій

Таблиця 1 - Активність СОД та КАТ у слизовій оболонці тварин з нормоергічним типом запалення при пародонтиті $(\mathrm{M} \pm \mathrm{m})$

\begin{tabular}{||c|c|c|c|c||}
\hline \multicolumn{1}{|c|}{ Показник } & Контроль $(\mathrm{n}=12)$ & $\begin{array}{c}\text { Сьома доба } \\
\text { експерименту } \\
(\mathrm{n}=12)\end{array}$ & $\begin{array}{c}\text { Десята доба } \\
\text { експерименту } \\
(\mathrm{n}=12)\end{array}$ & $\begin{array}{c}\text { Чотирнадцята доба } \\
\text { експерименту } \\
(\mathrm{n}=12)\end{array}$ \\
\hline СОД, од. акТ. & $0,483 \pm 0,008$ & $0,75 \pm 0,02^{\star}$ & $0,67 \pm 0,06^{\star \star}$ & $0,71 \pm 0,06^{\star}$ \\
\hline КАТ, мккат/кг & $0,499 \pm 0,01$ & $0,61 \pm 0,02^{\star}$ & $0,54 \pm 0,02^{\star \star}$ & $0,56 \pm 0,02^{\star \star}$ \\
\hline
\end{tabular}

Примітки. Тут і в таблицях 2 та 3 наведені результати достовірно відрізняються від показників контрольної групи тварин:

1. * $-p \leq 0,01$

2. ${ }^{* *}-p \leq 0,05$

Таблиця 2 - Активність СОД та КАТ у слизовій оболонці тварин з гіпоергічним типом запалення при пародонтиті (M $\pm \mathrm{m})$

\begin{tabular}{||c|c|c|c|c||}
\hline \hline Показник & Контроль $(\mathrm{n}=12)$ & $\begin{array}{c}\text { Сьома доба } \\
\text { експерименту } \\
(\mathrm{n}=12)\end{array}$ & $\begin{array}{c}\text { Десята доба } \\
\text { експерименту } \\
(\mathrm{n}=12)\end{array}$ & $\begin{array}{c}\text { Чотирнадцята доба } \\
\text { експерименту } \\
(\mathrm{n}=12)\end{array}$ \\
\hline СОД, од. акТ. & $0,483 \pm 0,008$ & $0,66 \pm 0,02^{\star}$ & $0,50 \pm 0,02$ & $0,43 \pm 0,07$ \\
\hline КАТ, мккат/кг & $0,499 \pm 0,01$ & $0,54 \pm 0,01^{\star *}$ & $0,51 \pm 0,02$ & $0,41 \pm 0,04$ \\
\hline
\end{tabular}

Таблиця 3 - Активність СОД та КАТ у слизовій оболонці тварин з гіперергічним типом

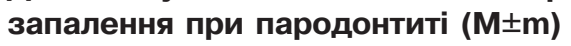

\begin{tabular}{||l|c|c|c|c||}
\hline \multicolumn{1}{|c|}{ Показник } & Контроль $(\mathrm{n}=12)$ & $\begin{array}{c}\text { Сьома доба } \\
\text { експерименту } \\
(\mathrm{n}=12)\end{array}$ & $\begin{array}{c}\text { Десята доба } \\
\text { експерименту } \\
(\mathrm{n}=12)\end{array}$ & $\begin{array}{c}\text { Чотирнадцята доба } \\
\text { експерименту } \\
(\mathrm{n}=12)\end{array}$ \\
\hline СОД, од. акТ. & $0,483 \pm 0,01$ & $0,77 \pm 0,03^{\star}$ & $0,81 \pm 0,03^{\star}$ & $0,82 \pm 0,02^{\star}$ \\
\hline КАТ, мккат/л & $0,499 \pm 0,01$ & $0,63 \pm 0,07^{\star}$ & $0,97 \pm 0,07^{\star \star}$ & $1,27 \pm 0,03^{\star}$ \\
\hline
\end{tabular}


оболонці пародонта тварин 3 гіперергічним типом запалення вказує на посилення ферментної ланки антиоксидантного захисту для стримування розвитку окисного стресу.

ВИСНОВКИ. 1. Супероксиддисмутаза і каталаза у всіх групах дослідження змінювалися порівняно з контролем, і їх активність залежала від терміну дослідження та типу запальної реакції.

2. При нормоергічному типі запалення активність ферментів АОС була вищою впродовж усього дослідження. Це свідчить про те, що в даній групі тварин відзначали достатню ефективність антиоксидантного захисту.

3. У групі тварин з гіпоергічним типом запалення активність СОД та КАТ була незначно вищою від контролю лише на сьому добу експерименту. На десяту і чотирнадцяту доби дослідження активність ферментів АОС достовірно щодо контролю не змінювалася, що може свідчити про зниження рівня антирадикального захисту тканин пародонта.

4. У тварин з гіперергічним типом запальної реакції відбувалося найбільш виражене зростання активності ферментів СОД та КАТ у слизовій оболонці пародонта. Це дає підставу вважати, що в даній групі дослідження місцева адаптивна реакція є найвищою.

Перспективи подальших досліджень. У майбутньому доцільним буде дослідити показники системи антиоксидантного захисту в різні періоди експериментального пародонтиту за умови застосування коригувальних чинників.

\section{СПИСОК ЛІТЕРАТУРИ}

1. Абасканова П. Д. Перекисное окисление липидов и системы антиоксидантной защиты мембран эритроцитов, плазмы крови у кроликов с искусственно вызванным пародонтитом и влияние различных методов лечения / П. Д. Абасканова // Медицина и образование в Сибири. - 2011. - № 1. C. 11-16.

2. Авдєєв О. В. Динаміка перекисного окиснення ліпідів і стану антиоксидантної системи у пародонті в експерименті / О. В. Авдєєв, А. Б. Бойків // Вісник стоматології (спецвипуск). - 2012. - № 6 (79). C. 2-4.

3. Антиоксидантная терапия в комплексном лечении пародонтита / П. В. Иванов, И.В.Маланьин, А. В. Стоматов, Ю. В. Грибовская // Фундаментал. исследования. - 2008. - № 11. - С. 23-27.

4. Владимиров Ю. А. Перекисное окисление липидов в биологических мембранах / Ю. А. Владимиров, А. И. Арчаков. - М. : Медицина, 1972. 252 c.

5. Воложин А. И. Патогенез экспериментального пародонтита у кроликов / А. И. Воложин, С. И. Виноградова // Стоматология. - 1991. - № 4. - С. 10-12.

6. Годована О. І. Аспекти етіології та патогенезу запальних і дистрофічно-запальних захворювань пародонту / О. І. Годована // Новини стоматології. 2010. - № 3. - С. 69-73.

7. Грудянов А. И. Этиология и патогенез воспалительных заболеваний пародонта / А. И. Грудянов, Е. В. Фоменко. - М. : Медицинское информационное агентство, 2010. - 96 с.

8. Деньга О. В. Антиоксидантно-прооксидантная система десны при экспериментальном периодонтите и его лечении / О. В. Деньга, Л. Б. Цевух, А. П. Левицкий // Укр. стоматол. альм. - 2008. № 2. - C. 10-11.
9. Курбатова С. С. Патогенетичне лікування хворих на генералізований пародонтит: обгрунтування, ефективність, прогноз : автореф. дис. на здобуття наук. ступеня канд. мед. наук / С. С. Курбатова. Івано-Франківськ, 2007. - 21 с.

10. Метод определения активности каталазы / М. А. Королюк, Г. И. Иванова, Н. Г. Майорова [и др.] // Лаб. дело. - 1988. - № 1. - С. 3-8.

11. Мисула І. Р. Морфологічні зміни серцевого м'яза щурів при гіпоергічному та гіперергічному перебігу адреналінової міокардіопатії в експерименті / І. Р. Мисула, А. Б. Бойків // Здобутки клініч. і експерим. медицини. - 2008. - № 1 (8). - С. 47-50.

12. Назарян Р. С. Динаміка моделювання порушень прооксидантно-антиоксидантного гомеостазу в організмі та тканинах пародонта щурів / Р. С. Назарян, В. В. Гаргін // Актуал. проблеми суч. медицини. - 2007. - 7, вип. 4 (20). - С. 34-37.

13. Науково-практичні рекомендації з утримання лабораторних тварин та роботи з ними / [Кожем'якін Ю. М., Хромов О. С., Філоненко М. А., Сайфетдінова Г. А.]. - К. : Авіцена, 2002. - 156 с.

14. Чевари С. Роль супероксиддисмутазы в окислительных процессах и метод определения ее в биологическом материале / С. Чевари, И. Чаба, Й. Секей // Лаб. дело. - 1985. - № 11. - С. 678-681.

15. Bulkina N. V. Modern aspects of inflammatory periodontal disease. Etiology and pathogenesis. Features of refractory periodontitis. Clinical manifestations / N. V. Bulkina, V. M. Morgunova // Scientific Journal Fundamental Research. - 2012. - 2. P. 415-420.

16. Charlene W. J. / The microbial Aetiology of Periodontal Diseases // Periodontal Diseases A Clinical's Guide. - New York, 2012. - P. 3-54. 
И. Я. Цвынтарная

ТЕРНОПОЛЬСКИЙ ГОСУДАРСТВЕННЫЙ МЕДИЦИНСКИЙ УНИВЕРСИТЕТ ИМЕНИ И. Я. ГОРБАЧЕВСКОГО

\section{ДИНАМИКА ПОКАЗАТЕЛЕЙ АНТИОКСИДАНТНОЙ ЗАЩИТЫ СЛИЗИСТОЙ ОБОЛОЧКИ ПАРОДОНТА В УСЛОВИЯХ ЭКСПЕРИМЕНТАЛЬНОГО ПАРОДОНТИТА ПРИ ИЗМЕНЕННОЙ РЕАКТИВНОСТИ ОРГАНИЗМА}

\section{Резюме}

Исследованы особенности изменений активности ферментов антиоксидантной защиты в слизистой оболочке пародонта животных. Установлено, что в группе животных с нормоергическим типом воспалительной реакции активность супероксиддисмутазы изменяется в сторону повышения несущественно, а каталазы - колеблется в пределах контроля. У животных с гипоергическим типом воспалительной реакции активность ферментов антиоксидантной защиты изменяется только на седьмые сутки эксперимента. В группе животных с гиперергическим типом воспаления происходит активация ферментов антиоксидантной защиты, и их активность является самой высокой из всех исследуемых груп.

КЛЮЧЕВЫЕ СЛОВА: пародонтит, типы воспалительной реакции, антиоксидантная система.

I. Ya. Tsvyntarna

I. YA. HORBACHEVSKY TERNOPIL STATE MEDICAL UNIVERSITY

\section{DYNAMICS OF PARAMETERS OF ANTIOXIDANT DEFENSE OF ORAL MUCOUS MEMBRANE IN EXPERIMENTAL PARODONTITIS WITH MODIFIED REACTIVITY}

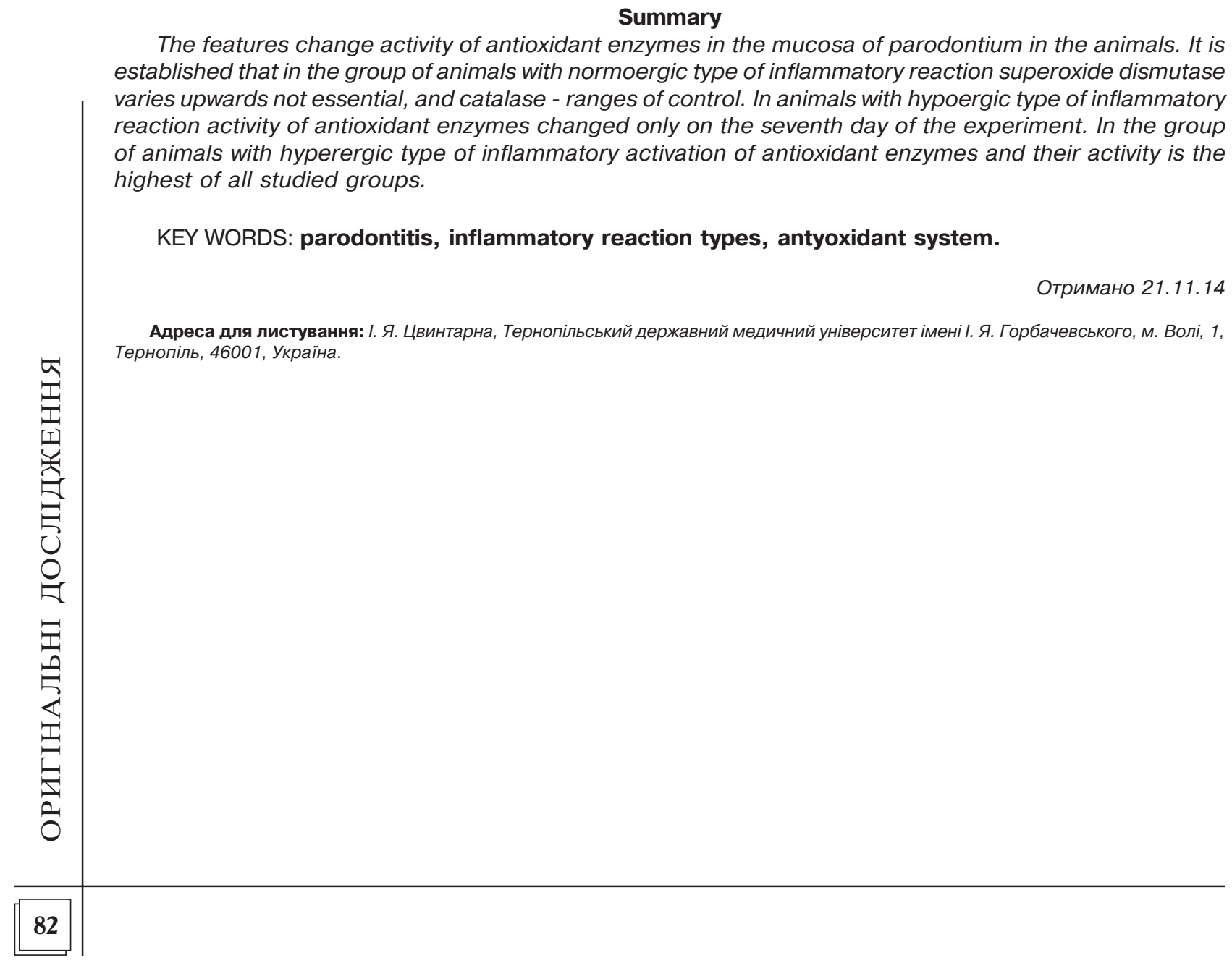

